\title{
Varicella-Zoster Virus Antibody
}

National Cancer Institute

\section{Source}

National Cancer Institute. Varicella-Zoster Virus Antibody. NCI Thesaurus. Code C118486.

Any immunog lobulin that recognizes the varicella-zoster virus. 